\title{
THE ROLE OF ESTATE GARDEN ALLOTMENTS IN THE SOCIOECONOMIC DEVELOPMENT OF TAMIL LABOURERS IN THE FEDERATED MALAY STATES, 1900-1941
}

\author{
Thivya Ranie Perumal* \\ Sivachandralingam Sundara Raja** \\ History Department, Faculty of Arts and Social Sciences,
University of Malaya (UM), Malaysia
}

\begin{abstract}
The article evaluates the extent to which estate garden allotments in the Federated Malay States (FMS) contributed to the socioeconomic development of Tamil labourers from the opening of the $20^{\text {th }}$ century until 1941. By the late nineteenth century, the British government had initiated an immigrant agriculture policy in response to the need of preserving sufficient labour force to service the industrial economy. The extensive development of rubber industry from the early twentieth century, however, led to the permanent revocation of the policy, considering extensive immigration of large numbers of Tamil labourers was guaranteed through the Tamil (later, Indian) Immigration Fund Ordinance. Nevertheless, the policy did resurface from time to time during periods of economic recession following the First World War from 1917 and the Great Depression in the 1930s. It was when industrial slowdown compelled the British administration and rubber capitalists to preserve as many labourers as possible. The strategy was to induce them in undertaking allotment farming, which was embodied in the 1928 Labour Code. This article serves a twofold purpose. First, to analyze the extent to which the allotments on selected estates were able to alleviate the socioeconomic problems of the Tamils and; secondly, to evaluate the possibility of their transforming into agriculturalists and small-scale food vendors. The final part highlights allotment units, foodstuff cultivation and livestock farming as essential ingredients required for the socioeconomic functioning of estate agricultural allotments.
\end{abstract}

Keywords: Federated Malay States, Tamils, Allotments, Foodstuff Cultivation, Livestock Farming

\section{Introduction}

For quite a long time in the writings of the history of agricultural development and undervelopment in the Federated Malay States (FMS), the emphasis among scholars has often been in the various economic and social aspects relating to the primary industries, namely tin and the comparably more successful rubber. ${ }^{1}$ In all fairness, both sectors undoubtedly characterized a major segment of nineteenth and early twentieth-century Malaysian economic history owing to their role in stimulating substantial amount of capital inflow, extensive land opening, infrastructural growth, revamps in labour immigration policies, and even structural changes to the political environment. ${ }^{2}$ The economic policy of the British administrators in the Malay states to bring about a rigorous development in both sectors, particularly rubber, saw as a result the concentration of state machineries and economic resources solely for the development of both industries. This created not only an environment of dualistic economic growth but also extreme socioeconomic disparity between the capitalist and administrative classes and the immigrant labour and native peasant classes, where the latter were the least privileged groups. ${ }^{3}$ In the midst of intense development of 
capitalist agriculture represented chiefly by rubber development from the early twentieth century, small-scale, farming-level agricultural activity involving both groups was also taking place at the same time in the country. As the historical roles of the Malay peasants and their agricultural endeavors are well documented, existing works pay only scant attention to that of the immigrant labour force. This article is thus chiefly concerned with the involvement of the south Tamil working-class, who were recruited to service the rubber industry, in undertaking agricultural initiatives and the extent to which their socioeconomic deprivation was alleviated as a result.

The historical backdrop for the matter in question is traceable to the economic environment of the FMS from the late nineteenth century. By 1895, the FMS administration had implemented a peasant agricultural policy in order to attract and encourage peasant agriculturalists, mainly among the Malays and, to a lesser extent, immigrant settlers to open up agricultural lands and cultivate subsistence food crops. ${ }^{4}$ The basic purpose of the policy was, purportedly, to provide a platform for the settlers to fulfill their daily needs and produce marketable food crops for local supply. ${ }^{5}$ As far as the immigrants are concerned, there was an economic angle attached to the policy; by encouraging immigrants particularly of the labour class to settle on lands, it was hoped that they would one day provide useful labour for future industries. In addition to this, the FMS government wanted to also create a stable population of peasant agriculturists because the value of agricultural exports was considerably lower than the total export value of the mainstay tin industry. By promoting peasant agriculture, the administration wanted to transform a substantial number of local Malays into agriculturalists to cultivate paddy for their own dietary needs and that of the increasing number of immigrant labourers. ${ }^{6}$ The administration also hoped to increase the influx of immigrant labourers of agriculturalist potential through the liberal immigration policy of 1891 so that they could be utilized, whenever necessary, for local food production. It therefore quickly became the general preference of British administrators that only immigrants, including labourers, among bona fide agriculturalists should be recruited and granted agricultural lands.

Due to the said preference, in addition to the local Malays, the FMS administration also encouraged those among the "other Malaysian" immigrants to establish a peasant agricultural base by the late nineteenth century. The British hoped to induce the immigration of "Malaysian subsistence farmers (from the Archipelago)" to settle on agricultural lands "with their families" through a liberal immigration policy. Mainly to reduce Malaya's dependence on Siam for rice importation, the administration wanted to encourage them to take up domestic food production by settling on agricultural lands. ${ }^{7}$ The ultimate purpose was to create a population capable of cultivating subsistence crops (to fulfill their dietary needs) and marketable food crops (for local supply). As mentioned earlier, it is also not unlikely that the policy was thought to create a reusable labour reservoir in the long run.

In line with this policy, in the early 1900s, the FMS government briefly contemplated the granting of land as an incentive to settle south Indian labourers, mainly among the Tamils, who were recruited to plantations. The large-scale distribution of labourers through the Tamil (later, Indian) Immigration Fund Ordinance from 1907, however, prompted colonial administrators to abandon the initiative from ever becoming a statewide policy. The responsibility was now passed to private estates to allocate land allotments for their labourers if they wanted to preserve them for future labouring. In order to preserve their labour, the strategy used was that the socioeconomic position of the Tamil labourers was to be stabilized by allowing them to conduct subsistence farming. ${ }^{8}$ Those unemployed during the post-First World War economic recession were particularly expected to undertake expedient socioeconomic measures - mainly foodstuff cultivation on estates for vegetable supply. In the 
wake of the Great Depression in the 1930s, a stable population of labourers was urgently required for post-recession industrial use. ${ }^{9}$ The FMS government subsequently pushed estate managements to grant garden allotments to preserve as many Tamils as possible. The Labour Code was subsequently amended in 1928 , enforcing estate plantations to allocate $1 / 16^{\text {th }}$ of an acre for their labourers. ${ }^{10}$ Following that, rubber estates began opening up allotments for their labourers to cultivate subsistence food crops by initiating subsistence-level agricultural cultivation. Garden allotments became the main recourse for planters with labourers who refused repatriation during the Great Depression. ${ }^{11}$ During this period, the Labour Code was actively enforced to ensure agricultural lands were allocated so that the produce of the lands could provide them an alternative source of income for them to stabilize their position on estates.

However, well-cultivated estate gardens were only not many in numbers. It is with the few several notable gardens that this article wishes to concern itself with. Four experimental Tamil estate gardens established in the period 1919-1941 are selected for this purpose, namely the Dindings (Perak), Sungei Ujong (Negeri Sembilan), Permatang (Selangor) and Rubana (Perak). These garden allotments received the attention of the Labour Department and the Department of Agriculture for being exceptional in terms of anticipated future success and longevity. As such, they offer appropriate case studies for the article to undertake its more specific purpose of evaluating to what degree garden allotments benefited the settlers, or in other words, the labourers themselves, in fulfilling their socioeconomic needs and upgrading their position into small-scale agricultural vendors.

\section{Socioeconomic Functions of Estate Garden Allotments}

\section{Dindings Coconut Estate, Perak}

The Dindings Coconut Estate, located in the coastal district of Dindings in western Perak (originally in the Straits Settlements) was among the earliest to establish garden allotments for the south Indian labourers. ${ }^{12}$ The labour force consisted mostly of the Tamils, who had been recruited in large numbers by the turn of the twentieth century when plantation agriculture took off in the district. ${ }^{13}$ In responding to the government's call for the enlargement of the subsistence base of the country - mainly due to unemployment and food crisis during and following the First World War - the Dindings estate management decided to establish agricultural gardens for their labourers to grow subsistence foodstuff. ${ }^{14}$ It was decided to be an experiment, however, in order to identify appropriate crops to be cultivated by the Tamils for subsistence living. The ultimate intention was to retain sufficient labour force on the estate.

Although the exact year of their establishment is unknown, the gardens were likely established between 1913, when the volume of Malayan export trade showed a decreasing trend, and 1916, when the government attempted to promote the cultivation of staple foodstuff on estates due to rice shortage. In 1916, the Dindings Estate attempted to grow wet paddy on the estate's clay alluvial soils using the labour of the Tamils. ${ }^{15}$ Unfortunately, due to their limited knowledge of paddy cultivation, the attempt did not take off as expected. Alternatively, the Tamils cultivated fresh vegetables on their garden allotments. Some even managed to sell their surpluses. In 1917, the labourers took an initiative to cultivate millet (kelvaragu in Tamil) in their spare time. Compared to other, they had greater inclination for millet planting, as they had already been accustomed with this particular cultivation in south India. ${ }^{16}$ Evidently, according to W.S. Cookson, there was no difficulty in persuading the 
Tamils to plant millet, as their eagerness was high. ${ }^{17}$ Millet harvesting was then carried out on estate accounts. Since the planting of millet was successful, additional efforts were made in the growing of other foodstuff on the gardens. At one point, nearly all male labourers were called for and were given small plots of land for the cultivation of young coconuts in their spare time. ${ }^{18}$ However, coconut planting was only fairly successful, as millet was still their preferred crop. Their penchant for millet cultivation explains why the labourers did not undertake livestock keeping.

Bearing in mind of the economic recession at that time, two reasons could have motivated them to undertake subsistence agriculture on garden allotments. Firstly, a number of them might have thought of earning additional income on top of their wage. The gardens were their only source of income, especially for the unemployed ones. Secondly, they were able to trade self-grown millet for other staple foods, mainly rice, which soar high due to food shortage. ${ }^{19}$ By facilitating them to conduct millet trading and a simple form of barter exchange for rice, the socioeconomic position of the south Indian labourers was therefore strengthened, and subsequently the labourers were preserved.

Over time, the production of millet surprisingly reduced the requirement for rice among the labourers on the Dindings Estate. As millet was proven to be economical, the estate management provided further assistance for their labourers to cultivate the crop. It once purchased 7 stone-grinding mills of the Tamil type at $\$ 5$ each and were distributed free of charge to the labourers. ${ }^{20}$ With the help of this machine, they were able to grind enough flour on weekends for regular consumption. As a result, most were able to spare enough time daily for its preparation before leaving for estate works. They were also able to familiarize themselves with a systematic manner of production by learning to operate grinding machines. Millet in general was one of the crops suggested for cultivation on estates where Tamil labourers worked, as it could be easily grown and was as high in dietary value as rice and long lasting. ${ }^{21}$ It was therefore a highly suitable supplementary food item over rice, which was subject to rationing due to the recession. ${ }^{22}$

Millet produced on the Dindings estate was sold among the labourers at a price not exceeding 20 cents per gantang. ${ }^{23}$ As a result, the estate management was able to reduce the cost for imported rice and successfully absorbed the Tamil labourers into adopting subsistence cultivation, particularly millet, to overcome food shortage. They also earned additional income by selling vegetables.

However, there were some problems that inhibited the labourers from sustaining their cultivations on the allotments. As they were only used to simple millet cultivation, the labourers were not able to adopt the more methodical approach suggested by the estate management. For example, they found it difficult to undertake post-planting care and maintenance. The labourers also faced difficulty in ploughing the land and almost always failed to keep the land properly weeded. They were then instructed to cultivate in groups under the constant supervison of the estate manager. Lands were thoroughly dugged and seeds were raised in nurseries and transplanted on the plots. Their plots were surveilled by watchmen who were also tasked to keep off birds and pigs. However, the planting of millet was seasonal in nature. The labourers would have likely reverted to estate labouring in the 1920 s when the price of rubber rose. ${ }^{24}$ Presumably, the allotments might have been gradually abandoned by 1935 when the settlers were probably repatriated together with thousands of Tamil workers from June 1930 during the Great Depression. ${ }^{25}$ 


\section{Sungei Ujong Estate, Negeri Sembilan}

Sungei Ujong Estate was a rubber plantation owned by the United Sua Betong Rubber Company. ${ }^{26}$ In the wake of the Great Depression in 1930-1932, the management predicted that a large number of its labour force might not be needed for the time being. It however suggested that there will be a huge demand for south Indian labourers after 1935. As an early precaution, the Tamil Colonisation Scheme was launched to establish a settled population of labourers on the estate. It was planned and supervised by Graham Henderson with the assistance of Captain L.D. Gammans. ${ }^{27}$ The experiment, first mooted in July 1932, consisted of a total of 585 acres of land alienated for smallholding experimentation for a 3-year lease period and a rent of $\$ 1.50$ per acre per family of existing Tamil estate labourers. ${ }^{28}$ The entire block was pegged out into 2-acre plots. Each labourer would receive 2 acres in the first instance. Another 2 acres were to be reclaimed and cultivated with paddy ${ }^{29}$ Although Ganapathy, the management's chairman, agreed to the plan, the other directors doubted the actual capability of the labourers in working out four to five acres of agricultural lands. ${ }^{30}$ Henderson clarified that the smallholdings were to encourage the permanent settlement of the Tamil labourers and that even if they refused or unable to work on the estate their children could replace them in the future.

It was initially opened up on some 230 acres of lands in 1933 and was directed and controlled by the management committee consisting of the Co-operative and Agricultural Officers. ${ }^{31}$ On special consideration, each labourer with family dependents was allocated up to 5 acres of land for cultivation and house erection. These were intended to be of use for the subsequent generation of labourers so that they could be permanently settled on the estate. At the end of 1935, 29 settlers and their families succeeded in opening up and cultivating an area of about 80 acres. $^{32}$ Ten houses were erected and fully occupied. The dried, lalang-filled and partly swampy lands were not suitable for rubber or cocoa cultivation but ideal for coconut and coffee cultivation. Seeds to plant arecanuts, coconuts and fruit trees were obtained from the Serdang Experiment Station. Selected strains of coffee were also raised in the nursery setup on some allotments.

The FMS Labour Department opined that the garden allotments on the estate were poised to fully develop in the future. ${ }^{33}$ Unfortunately, the outcome was on the contrary. At first, a total of 30 families had wanted to take up 241 acres. In 1934, 28 families settled on 77 acres. In the same year, one settler absconded to India and 7 smallholders withdrew from the scheme. By 1935, out of the 29 settlers and their dependents, who were expected to cultivate a total of 80 acres, only 10 settlers ended up cultivating a total of 70 acres. ${ }^{34}$ By the end of 1936, only 5 out of 10 members settled and cultivated their allotments. ${ }^{35}$ Surprisingly, the Director of Co-operative Society of the FMS and Straits Settlements was quite optimistic in stating that it was nevertheless a successful land settlement scheme in Negeri Sembilan. ${ }^{36}$

Generally, official view did not take into account the on-the-ground constraints faced by the settlers. The cultivable crops of arecanuts, coconuts and fruit trees did not provide sufficient staple foods for individual consumption and, therefore, could not be to fellow labourers. Additionally, the labourers were not able to undertake vegetable gardening and animal rearing due to the dry and swampy soil of the allotments. As a result, the settlers might not have lost the motivation to cultivate the crops, which they considered to be of little value for daily dietary consumption and for local sale. Another limitation was that the settlers were only able to acquire a lease of the land. As such, they were likely to be evicted by the management. ${ }^{37}$ Limited occupation tenure was, nevertheless, probably only a secondary 
concern. The more pressing problem was the inconsumable and unprofitable food crops that they were required to cultivate on their allotments.

Despite of the problems, efforts were made to stimulate interest among the labourers to cultivate, but were to no avail when there was a rise in the price of rubber and wage rates. In 1936, there were only 14 leases of agricultural plots signed up by the labourers. ${ }^{38}$ Another problem that resulted in the underdevelopment of the allotments was the lack of water sources for continuous cultivation. The management of the Sungai Ujong Estate was evidently more concerned with preserving their labour force than to establish a well-planned labour agricultural settlement. One positive outcome from the scheme is that the incorporation of the labourers into the estate's co-operative society enabled them to invest their savings and practice thrift living. However, the inability to harvest consumable and saleable crops explain why the labourers eventually lost interest in their allotments by 1935 .

\section{Permatang Estate, Selangor}

The allotments on the Permatang Estate were notable labour smallholdings during the Great Depression in the FMS. The allotments were established on some 63 acres of alluvial and sandy loam, situated between the plantation area and the seashore, which was roughly one mile to the northwest of Morib. ${ }^{39}$ The establishment process commenced in November 1936. When it was proposed to set aside reserved lands for agricultural allotments, the Director of the plantation sanctioned a sum of money for jungle clearing. ${ }^{40}$ Lands unsuitable for rubber were allocated for the benefit of the aged members of the labour force wishing to retire, mainly the Tamils, and those who refused repatriation. They were to be settled on the estate to live with their family members. ${ }^{41}$ The scheme was intiated based on the idea of getting a number of non-labouring dependents (the aged ones) to take up blocks of agricultural lands to contribute extra income to their family. It was also designed to assist the unemployed ones. Some were descendants of the first batch of labourers who arrived at the estate. They had resided on the estate for more than 20 years and never once visited India. The allocated area was divided into one-acre blocks, each measuring 5 chains by 2 chains for the settlers to build houses and undertake subsistance cultivation. ${ }^{42}$ A quit rent of $\$ 0.25$ was charged for each acre of land per annum. ${ }^{43}$

Initially, the Tamil workers were not receptive to the scheme. ${ }^{44}$ The estate management had to provide encouragement for them to start up agricultural cultivation on the given plots. A drainage system was built and water was supplied through canals to each block of land; there was apparently no incidence of dispute among the labourers over water source. ${ }^{45}$ The estate also provided attap roofs for the labourers to build their houses on the allotments. They were, nevertheless, required to bear the overall cost ranging from $\$ 10$ to $\$ 15$ each. ${ }^{46}$ Attaps, for example, varied between $\$ 12$ and $\$ 25 .{ }^{47}$ The piggeries and goat pens cost between $\$ 5$ and $\$ 15 .^{48}$ The management hoped that the labourers would take their own initative in matters relating to cultivation and maintenance of their holdings. Nine labourers were successfully persuaded by an officer of the Co-operative Department to settle on the allotments. ${ }^{49}$ Chinese gardens, on the other hand, had been set up nine months before lands were allocated to the Tamils. They were built on three acres of land on which squatters were also opened. The Chinese garden allotments often served as demonstration plots for the Tamils to learn effective cultivation methods. ${ }^{50}$ The Chinese gardens also sometimes supplied seeds for the Tamil labourers' gardens. ${ }^{51}$ 
The Tamil workers were eventually persuaded to settle on allotments to undertake subsistence farming. ${ }^{52}$ In 1938, a total of 30 acres were opened up for cultivation and 5 acres reserved for grazing. ${ }^{53}$ By the end of 1937 , there were 17 families residing on the allotments. The labourers and their dependents who lived in lines took up 12 holdings. It was estimated that the labour gardens comprised of 23 men, 21 women and 33 children. ${ }^{54}$ In 1938, there were 35 holdings of one acre each with 82 settlers. A total of 28 cheap cottages were also erected. ${ }^{55}$ Usually, the husbands would work the agricultural plots while the wives worked on the plantation. ${ }^{56}$ Relatives living in estate lines about $1 \frac{1}{2}$ miles away would also help them cultivate the plots in the afternoons. ${ }^{57}$ As more individuals were available to contribute productive labour, the subsistence economy of the holdings was strengthened. ${ }^{58}$ Even in 1940, there were a total of 37 holdings on the estate. ${ }^{59}$ The non-labouring elderly labourers were also involved in cultivation. Social problems, such as loitering, quarrelling, and physical confrontation as well as theft were uncommon.

Permatang settlers cultivated vegetables mainly for their own consumption and for local sale. Apart from tapioca and sweet potato, other principle crops grown were sugarcane, claddy, chillies, brinjals, beans and millet. Rice, however, was purchased. ${ }^{60}$ The labourers did attempt to diversify their economic activities. ${ }^{61}$ Besides cultivating colocasia (ubi keladi), the labourers conducted livestock farming of pigs and goats for their meat and cows for their milk. $^{62}$

The wastes from those animals were used as livestock manure for their cultivations. Manure from the large herd of pigs was used for the cultivation of coconut and rubber trees. Each settler was also given female kids (young goats). After their holdings were planted up, it would be registered in a Goat Breeding Society, enabling a registered male goat to be obtained for breeding purpose. ${ }^{63}$ It was also reported that until 1940 each Permatang settler owned pigs and goats and cultivated their plots with mostly vegetables. ${ }^{64}$ Besides providing useful nutrients for the settlers and their dependents, milk and meat were sold off for extra income. ${ }^{65}$ Together with self-grown vegetables, their diet was presumably well balanced. It has been stated in the Labour Department's Annual Report for the year 1937 that the health condition of the settlers was largely satisfactory with no cases of malnutrion-related diseases or any deaths due to chronic illnesses.

Pig rearing was especially encouraged, as this generated quicker profits. Cattle were fewer in number because of the high capital outlay required for their rearing. It was also costly to purchase the Indian and Siamese breeds. ${ }^{66}$ However, there was an intention to enlarge cattle herds to increase milk supply, especially since grazing grounds were readily available. Tapioca and sweet potato, apart for their own consumption, were also used for feeding their livestock. The settlers sold pigs and goats to local buyers. In order to protect the settlers from being swindled by the buyers, the Permatang Estate management itself arranged the sale of pigs. In the early stages, the settlers also attempted poultry keeping. However, both the management and the settlers agreed that this had to be discontinued, as they often damaged the food crops on cultivated plots. ${ }^{67}$ According to Milsum of the Department of Agriculture, the Permatang settlers were better off rearing cattle and goats on the estate and penning them during the night. ${ }^{68}$

By the end of 1936, the gardens were developed with the support of the estate management and the hardworking nature of the labourers. The Labour Department even recognized the experiment as one of the most interesting, promising, and instructive. ${ }^{69}$ The Department of Agriculture estimated that the overall revenue capable of being generated from 
the holdings amounted to about $\$ 2,016 .^{70}$ This amount did not include the total value of production, since the holders and their dependents consumed a portion of their cultivations.

Paton, the estate manager, mentioned that the profits generated from sale of allotment produce were as large as the savings of the settlers. The settlers also invested a portion of their savings into the estate's co-operative society, which is said to be a well-organized one in the FMS. ${ }^{71}$ Another reason that contributed to the success of the Permatang allotments is the intiative taken by the labourers to learn useful cultivation techniques. The settlers, for example, participated in the Kuala Langat Agricultural Exhibition held in October 1938. During the event, they managed to win 9 out of the 17 prizes, despite only having had two days of notice on the commencement of the exhibition. ${ }^{72}$ This clearly indicates the level of preparedness of the labourers and that they had already been actively engaged in agricultural cultivation.

The lines and holdings were said to be mostly satisfactory and well kept to allow more room for agricultural cultivation. However, the drainage system was not up to the mark, calling for an immediate action by the management. The settlers built simple, weatherproof houses using mangrove poles (bakau), which they obtained from nearby swamps, and palmleaf panels (nibong). The floors were of the beaten-earth type plastered with cow dung. ${ }^{73}$ Some of the houses were designed in the form of cottages. Coconut trees were planted beside each house. This was where the settlers usually meet to discuss stock prices, problems in the neighbourhood and for social interaction in general. ${ }^{74}$

Livestock farming, particularly pig rearing, is an important economic activity undertaken by the Permatang settlers. ${ }^{75}$ Moreover, the success of the allotments is almost solely due to livestock rearing. The labourers were very much able to reuse the wastes of their livestock as manure for their cultivation, thus saving them a substantial amount of money on expensive manure sold elsewhere. In his letter dated 17 October 1941, Paton mentioned that the estate kept livestock on a fairly large scale in the 1930s for the purpose of manuring coconut cultivation. ${ }^{76}$

Table 1: Livestock on Permatang Labour Gardens from 1937-1940

\begin{tabular}{|l|c|c|c|}
\hline Livestock/Year & 1937 & $1938^{77}$ & 1940 \\
\hline Cattle & 6 & 13 & 12 \\
\hline Goats & 55 & 118 & 95 \\
\hline Fowls & 325 & Large number & 200 \\
\hline Pigs & 114 & 133 & 35 \\
\hline
\end{tabular}

Source: Annual Labour Report 1937, p. 46, Annual Labour Report 1938, p. 53, and Milsum and Grist, Vegetable Gardening in Malaya, p. 141. No data is available on the total number of livestock for the year 1939 
Goats and cattle were evidently large in numbers in 1937, as shown in Table 1. However, the large number of fowls in the same year frequently damaged young crops. According to Table 1, the fowls reared in the gardens outnumbered all the other livestock between 1937 and 1940. This is despite the management had initially planned to discontinue poultry keeping. The settlers, however, still kept large number of fowls in 1938 and 1940. Comparatively, there were only 6, 13 and 12 cattle kept in 1937, 1938 and 1940 respectively. ${ }^{78}$ Cow dung was used as manure and for brick making. Since the majority of the settlers were Hindus, the cows were also used to obtain milk for own consumption, local sale and religious purposes. ${ }^{79}$ As an alternative to fowls, some of the settlers opted to rear ducks in the latter years. While the number of goats fluctuated in 1937 and 1938, it increased from 55 to 118 and dropped to 95 in 1940. The number of pigs increased from 114 in 1937 to 133 in 1938 but dropped significantly to 35 in 1940. Despite the decrease, pig rearing was still a profitable economic activity for the settlers.

Food crop production was essential in the socioeconomic development of the Permatang settlers. Together with accessible source of water, the allotments were ideally situated on alluvial soils and sandy loam to enable food crop cultivation. The physically more-abled settlers often requested large agricultural holdings and some were allotted up to two acres for foodstuff cultivation. Most of them cultivated vegetables and sold out their surpluses in neighbouring roadside market. ${ }^{80}$ Like the settlers of the Dindings Coconut Estate, the Permatang settlers preferred millet to rice as their staple food. But unlike the Dinding settlers, the Permatang settlers were likely able to purchase rice whenever required, considering the substantial additional income generated from livestock rearing. The amount of money received from market sales was also fairly substantial, as a sum of it was even reinvested into the estate's Co-operative Society.

A setback, however, was that the labourers sometimes failed to properly preserve soil fertility, leading to crop failure. Although they were mostly receptive to the idea of subsistence and small-scale agriculture, as Paton indicated, no agricultural school was opened by the estate management to add to their knowledge on the various methods of cultivation. ${ }^{81}$

A prominent feature of the Permatang allotments is the idea of conducting livestock rearing along with food crop cultivation. ${ }^{82}$ As manure was mostly obtained from self-grown livestock, the settlers were able to cut cost and and supplement their income by increasing the production of marketable agricultural outputs. Even as late as 1938, T. P. Sundaram, the Assistant Controller of Labour in Klang, acknowledged the Permatang allotments for its progress and noted that housings and side occupations should be arranged for former labourers. ${ }^{83}$ The successful development of the allotments led the FMS government to announce that it was keen to promote more such schemes by reducing the amount of rent required to open up additional lands. ${ }^{84}$ The Labour Department also advised managers of other estates to establish allotments on their estates based on those opened on the Permatang estate. $^{85}$

How the Permatang allotments fared in the subsequent years is, however, unclear. In an interview that Sandhu conducted with one Pongaivanam, son of a kangani who was incharge of some pre-Second World War settlers on the estate, the labour gardens are said to have deteriorated during the Japanese occupation due to labour conscription. ${ }^{86}$ 


\section{Rubana Estate, Perak}

Garden allotments for Tamil labourers were also established on the Rubana Estate, situated in Lower Perak and six miles from Teluk Anson. ${ }^{87}$ The estate was among the first including the Sungei Tinggi and Bandar Estates - to be opened in the coastal areas of Perak. The precise year of the establishment of labour allotments on the estate is not recorded. The allotments were probably established between 1933 and 1935 in response to the Great Depression. As a matter of fact, their existence was mentioned in the 1937 Annual Report of the Labour Department, which also acknowledged that the allotments were successful experiments. The Labour Department once requested other estate managers to visit the Rubana smallholdings in 1936 to follow its model of opening "gardens between lines". ${ }^{8}$

The allotments were situated in a vast stretch of lands within the estate. Each labour lines was alloted a strip of land. ${ }^{89}$ The estate management allocated a total of 100 yards of land to develop quarters for labourers. ${ }^{90}$ Each working family was housed in a semi-detached building at the ground level. ${ }^{91}$ Each unit consisted of 5 detached buildings in a row where there were ten semi-detached cottages and each family had a bathing place inside the house. ${ }^{92}$ The allotments bordered with rubber trees and coconut trees on one side, as well as a railway track and a small cycling path on the other. It was K.H.C. Tobutt, the estate manager, who had decided to set aside agricultural lands adjoining the semi-detached houses. ${ }^{93}$ The agricultural lands measured $70 \times 30$ feet per family. ${ }^{94}$ The settlers took the responsibility of maintaining the houses, gardens and the whole living area. ${ }^{95}$

A wide grass path with shallow concrete drainage separated the front portion and each row of the houses. Trees were planted in the middle. Drains were built to protect the gardens and cottage houses from flood during monsoon seasons and to keep the housing area dry during rainy days. When the drains failed to function properly, the settlers had to dig a scupper drain in their cottage gardens. ${ }^{96}$ These drains served as decks to remove water. In 1938, 94 people inhabited the holdings and most of the lands were cultivated. ${ }^{97}$ The management also anticipated an increase in the number of cottage houses and lands to accommodate 48 families by the end of June 1939. ${ }^{98}$ The garden layout adjoining the labour cottages in the Rubana Estate is as shown:

Picture 1: Layout Plan of Rubana Labour Gardens

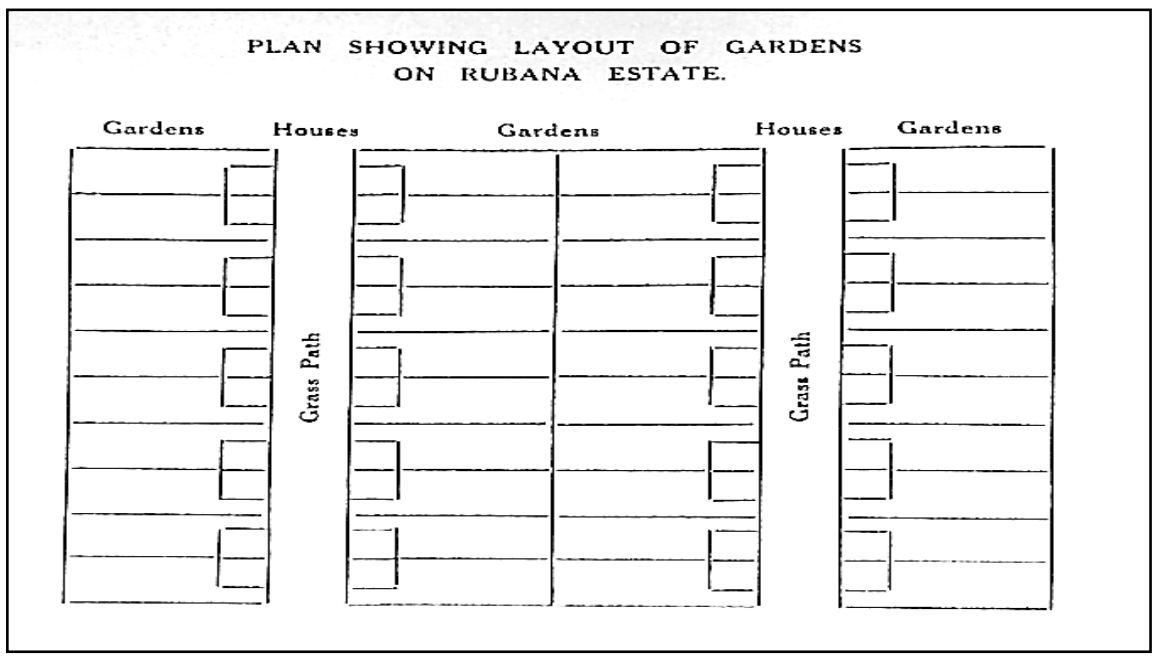

Source: "The Settlement of Tamil Labourers on the Land", The Malayan Agricultural Journal, p. 455. 
The gardens were mostly hand-cultivated by the labourers using a hoe. This had a tendency to produce coarse tilth. To solve this, the labourers built a trenching system to prevent the upper lining of the soil from mixing with the subsoil. Initially, the method of bed formation was unsatisfactory. A 4-feet wide bed typically found in Chinese market gardens was used as a standard measurement model for the Rubana garden allotments. ${ }^{99}$ Since the soil was moderately fertile and consisted of alluvial clay, it was ideal for vegetable cultivation.

Crop rotation did not take place because each garden cultivated several types of vegetable crops at once. ${ }^{100}$ As such, barter exchange between two families was not required, as each was able to self-supply. The fact that Rubana settlers "took pride" in their cultivations suggests that the allotments functioned more as individual family units. ${ }^{101}$ That is not to say simple exchange between families never took place. The availability of various types of crops could have encouraged them to practice sharing. Barter activity was, nevertheless, not obligatory and self-sufficiency was the dominant feature. Each family practiced intercropping to suit their dietary needs. Leguminous crops were also grown and its nitrogenous compound was a valuable organic fertilizer. ${ }^{102}$

Rubana settlers also engaged in the rearing of cattle and goats. Their wastes were used as organic fertilizers to improve aeration and tilth and to produce healthy agricultural produce. ${ }^{103}$ The estate management also distributed organic fertilizers and quality seeds. Labourers and their younger dependents were induced to conduct crop cultivation by encouraging them to attend demonstrative plots to learn cultivation methods and bed formation. ${ }^{104}$ Additional gardens were attached to cottages for demonstration. Two series of beds were raised and maintained and subsequently cropped based on simple rotation. The estate management supervised the labourers from time to time.

The physical arrangement of the cottage and the garden layouts contributed to the sustainability of the Rubana garden allotments. The settlers were very much able to perform farming near their lines. Every garden was fenced off by wire netting to prevent theft. ${ }^{105}$ The short distance between the gardens and nearby residential cottages encouraged labourers to work their agricultural lands on a regular basis. Although the money spent by the estate management for the cottage lines and labour allotments outweighed that required for the construction of labour lines, the output generated from the agricultural gardens made up for the expenditure. ${ }^{106}$ The total agricultural produce of an average labour garden was worth up to $\$ 2$ per month and about $\$ 6,000$ for the entire labour force per annum. ${ }^{107}$

Rubana settlers were considered healthy and contented due to their diet consisting of vegetables and legumes, which the labourers planted. Their health condition was a major concern for the management. Although initially the management showed reluctance, it soon expended substantially on mosquito eradication. This greatly reduced the spread of mosquitotransmitted diseases among the settlers. As a result, the labourers were able to engage themselves more regularly in crop cultivation without having to hold it off. This, in turn, promoted development to the extent that the Labour Department in 1938 reported that the allotments were some of the most successful ones. ${ }^{108}$ 


\section{Socioeconomic Indicators of Estate Garden Allotments}

\section{Allotment Units}

The extent of sustained development of the four agricultural holdings of Tamil labourers was partly conditioned upon the availability and usability of their allotment units. Agricultural allotments were essentially economic units for labourers to settle on and survive by cultivating subsistence foodstuff, especially during prolonged periods of unemployment. Estates usually allocated $1 / 16^{\text {th }}$ of an acre to their labourers for the purpose, as stipulated in the 1928 amendment of the Labour Code. Nevertheless, there were some estates that were willing to allocate larger allotments. ${ }^{109}$

As proven in the case of allotments on the Permatang and Rubana estates, those ranging between subsistence and small-scale commercial size provided sufficient room for the settlers to build cottages and pens for livestock farming. ${ }^{110}$ Reasonably-sized, economically-viable allotments also contributed to an increase in agricultural outputs, therefore capable of not only fulfilling the immediate subsistence needs of the labourer and his dependents but also enabling him to market the surplus to supplement his income.

However, it ultimately depended on the efforts of the labourers to put the allotments into effective use. The lack of agricultural undertakings on the agricultural allotments on the Sungei Ujong from 1933 to 1935 was due to the settlers' reluctance to cultivate non-staple and non-economical crops. They considered their allotments to be economically unremunerative even when they were unemployed and in the midst of food shortage during the Great Depression. By comparison, the Permatang and Rubana settlers utilized their holdings to the fullest extent by cultivating staple crops and rearing livestock.

The agricultural sustainability of a labour allotment was also influenced by the social relationship among the settlers themselves, as this provided a strong socioeconomic foundation. As individual/family allotments constituted the basic component of the larger settlement of labour gardens, the interaction among the labourers was a form of social capital highly essential for the community to function effectively. For example, the short distance between the allotments on the Rubana estate allowed for constant interaction, most likely during foodstuff exchange and casual gathering. ${ }^{111}$ Simple chitchatting also instilled a sense of belonging among the labourers. In short, an animated environment enabled them to work more of their allotments.

Additionally, the accessibility of allotments to nearby towns and plantation workplace were crucial for the successful development of agricultural activities. Plots that were near the main roads or water sources, as in the case of the Permatang allotments, were helpful for the labourers to transport their products to the nearest market and to ensure proper irrigation. Having said these, the physical characteristics of allotments alone would not be of great use without viable agricultural activities. Foodstuff cultivation and livestock farming are noticed to form another two essential ingredients for successful agricultural allotments.

\section{Foodstuff Cultivation}

The success of estate allotments during the post-First World War recession and the Great Depression depended on the extent to which these were able to provide consumable foods for the Tamil labourers and their dependents and surpluses to be sold off. ${ }^{112}$ The Food Production Enactment of 1918, which was passed to regulate rice production, attempted to promote foodstuff cultivation on estates in the FMS during the period of food shortage. The 
labourers were induced to stay on estates by cultivating their own vegetables or any type of food crops rather than having to rely on outside suppliers and the estate management. ${ }^{113}$ For this purpose, the Controller of Labour commissioned the establishment of a committee (between the post-First World War recession and the 1930s) to study the appropriate crops to be cultivated by the Tamil labourers. ${ }^{114}$ The vegetable crops recommended to be grown on their allotments are as shown:

Table 2: Selection of Suitable Crops to be Cultivated on South Indian Labourers' Garden Allotments

\section{SELECTED VEGETABLES}

Beans and Peas - Cluster Bean (Kottavarai), Cow Pea (Paythenkai), Egyptian Kidney Bean (Avarakai), Four-angled Bean (Murukavarai), Groundnut (Nella-kadalai), Lima Bean (Seemai-motchai), Pigeon Bean (Thovarai), Soya Bean (Malai thuvarai) and Sword Bean (Valavarai)

Tuberous and Root Vegetables - Elephant Yam (Karak-kavanai), Greater Yam (Vallikelangu), Lesser Yam (Kodi-kelangu), Jerusalem Artichoke, Sweet Potato (Sakkara Vallikelengu), Tapioca (Maravalli-kelangu), Taro (Shepang-kelangu), and Yam Bean (Taniuttankelangu)

Gourds and Pumpkin - Bitter Cucumber (Pava-kai), Bottle Gourd (Sura-kai), Cucumber (Vellari-kai), Loofah (Pekan-kai), Pumpkin (Parengi-kai), Snake Gourd (Podalan-kai) and Wax Gourd (Vella Pusani-kai)

Fruits Vegetables - Brinjal (Kathiri-kai), Chilli (Milagai), Lady's Fingers (Vendi-kai) and Maize (Makka cholam)

Leaf and Stem Vegetables - Amaranth (Pungkirai), Ceylon Spinach (Pasali-keerai), Chekur Manis (Thavasai murunggai), Horse-Radish Tree (Murunggai), Onion (Vengayam), Shallot (Sinna-vengayam) and West Indian Pea Tree (Agathi)

Flavoring and Seasoning Herbs - Ginger (Inji), Lemon Grass (Servi pullu) and Turmeric (Manjal)

Source: Milsum and Grist, Vegetable Gardening in Malaya, pp. 144-145.

More specifically, the committee reported that food crops such as banana, brinjal, Ceylon spinach, chekur manis, chilli, coriander, cucumber, lady's fingers, onion and sword beans were highly suitable to be cultivated on labour allotments. ${ }^{115}$ All but one of the four garden allotments discussed in the article are noticed to have cultivated their gardens with some of those crops specified by the committee. The gardens, in turn, exhibited 
socioeconomic stability and the settlers had an opening to venture into small-scale foodstuff vendoring.

An exception would be the gardens on the Sungei Ujong estate. The allotments were the least successful of the four experimental allotments. By comparison, the gardens were not established for the cultivation of any of those recommended food crops shown in Table 2 . This settlement was practically ill-conceived, as the unavailability of consumable staples and lack of opportunity to generate income meant little motivation for the labourers to cultivate their allotments. Instead, they would have preferred wage employment. The two criteria of foodstuff cultivation - consumability and saleability - were especially essential to provide food security for the labourers to sustain themselves during periods of unemployment.

Betel leaf cultivation, for example, possessed much economic value. In 1937, V.S. Sastri, a leader of the Indian Liberals who visited Malaya to investigate the conditions of south Indian labourers, mentioned that on some estates south Indians, mostly the elders, were fond of chewing betel leaves. Apart from consumption, a portion of these was also sold. Betel vine was also said to be one of the most profitable products on estates. ${ }^{116}$

On some estates, furthermore, labourers also sold their leftover vegetables to nearby toddy shops. Labourers who were habitual drinkers and who typically failed to cultivate their plots had to purchase foodstuffs from fellow labourers who did cultivate. By establishing an economic network among themselves within the estate environment, labourers of successful estate garden allotments such as on the Permatang and Rubana had the opportunity to transform themselves into becoming small-scale food sellers.

The Department of Agriculture also made an attempt to establish school gardens with a view of exposing the profitability of agricultural cultivation among the Tamil children on estates. It wanted to inform them that, contrary to common perception, farming and animal husbandry were not harmful to their dignity and self-respect, but were profitable economic activities. ${ }^{117}$ In an instance, a Field Staff from the Department of Agriculture assisted the Education Department in conducting these school gardens. ${ }^{118}$ The Department also conducted the Annual Agricultural Shows, which was a platform for the Tamil labourers to exhibit and market their products. It was expected that ultimately the encouragement would lead to the creation of a more stable population of local-born Tamil labourers.

A major stimulus for the Tamils to undertake food crop cultivation was the availability of seeds. Specifically in the case of the Sungei Ujong estate labour gardens, seeds were obtained from the Serdang Experimental Station. In the case of the Permatang labour holdings, seeds were obtained from Chinese agricultural gardens. The availability of seeds was a crucial motivating factor for the labourers to promptly clear lands and open up allotments, as proven in the case of the Permatang settlers.

Long-term foodstuff cultivation on labour allotments was also conditioned by the regular practice of crop rotation. This was practiced by the Rubana settlers, who grew different crops for their daily consumption. ${ }^{119}$ Another indication of socioeconomic progress can be seen in terms of good dietary balance owing to the consumption of self-cultivated vegetables. As in the case of the Dindings and, to a lesser extent, the Permatang gardens, labourers were better off cultivating millet instead of rice. The amount of carbohydrate from millet was sufficient and therefore did not necessitate the consumption of rice in any large 
amount. Besides millet, vitamins and minerals from vegetables and legumes also provided essential nutrients for the labourers.

\section{Livestock Farming}

Livestock farming was as important as foodstuff cultivation in promoting the development of labour allotments. One of the purposes of this particular activity was to reduce the import of goats for their meat. As suggested by $\mathrm{H}$. Walker, the manager of Kampar Estate, labourers who reared animals on estates eventually contributed to a decrease in the importation of goats. Profits obtained from livestock keeping also increased the purchasing power of the labourers who bred livestock locally. For this purpose, the Veterinary Department in Selangor had encouraged the production and improvement of local livestock. ${ }^{120}$ Some estate managers in Perak made efforts to undertake estate grazing as well as improving the stock and method of livestock rearing particularly of cattle and goats. ${ }^{121}$

The availability of natural manure through livestock farming provided essential organic material for successful food crop cultivation. As suggested by the Department of Agriculture, alluvial soils would be of no use for gardening purpose without adequate quantities of animal manure or compost. ${ }^{122}$ The Controller of labour also stressed the fact that successful allotments were indeed based on animal farming. The Department of Agriculture suggested that all agricultural allotments, with the exception of small vegetable allotments, included grazing reserves and livestock farming. ${ }^{123}$ Cattle rearing, pig keeping and poultry farming were supplementary economic acitivities that were encouraged to be conducted alongside vegetable gardening, as demonstrated in the case of the Permatang labour gardens; by providing manure for soil fertilization, the Permatang labourers were encouraged to grow more vegetables and other food crops.

During the Great Depression, animals reared on estates were also the source of useful nutrients for the labourers. While vitamin and minerals were obtained from vegetables, proteins and calcium were acquired from meat and milk respectively. ${ }^{124}$ As the majority of the Tamils were Hindus who refrained from consuming beef, they opted for chickens and goats for their meat. Eggs and fresh supply of cow milk were useful for children and infants. ${ }^{125}$ Moreover, with the availability of livestock, the labourers did not have to purchase meat from the market. These also provided surpluses for sale and, more importantly, own consumption in times of food rationing.

Like the case of the Permatang labour gardens, a herd of healthy cows in the Kampar estate were also useful in that they were able to milk out an average of 75 bottles of milk monthly. Each bottle had a market price of about 10 cents. A labourer could have earned approximately $\$ 7.50$ per month. ${ }^{126}$ Cattle rearing and milk supply were certainly profitable economic activites for Tamil labourers with animal grazing ground attached to their allotments. Some Permatang settlers even rose to become small-scale milk and dairy products vendors. ${ }^{127}$ In the event of gardening activity turning unfeasible, a labourer could still survive with the production of dairy products. Livestock farming was, thus, valuable investment, but was highly dependent on the availability of sizeable allotment and the adoption of proper animal husbandry method. 


\section{Conclusion}

Labour allotments owed their existence to the economic policy of the British administration and rubber capitalists to preserve sufficient labour force by allowing them to involve in shortterm agricultural cultivations. Although considered to be a temporary socioeconomic measure, estates gardens proved valuable as labourers were provided with the opportunity of safeguarding their livelihood particularly during the Great Depression and consequent unemployment and food crisis. Prior to the official encouragement through the 1928 Labour Code, labour gardens were established as early as in 1917 on the Dindings coconut estate. However, the economic activity was limited to food crop cultivation particularly millet for own consumption, with no surplus production and livestock farming undertaken. Evidence of barter economy is also noticeably absent. The post-First World War rice shortage saw the Tamil labourers on the estate survived by growing millet to substitute rice. Established during the recession in the 1930s, the Sungei Ujong allotment gardens were recognized by the Labour Department as one of the most socioeconomically promosing. In reality, however, the allotments did not take off as expected due to considerable lack of motivation among the labourers to cultivate agricultural crops, which were largely unsuitable for consumption. It also failed because the settlers had no prior experience in paddy cultivation. They were also unable to cultivate food crops on muddy and waste soils. The settlement was also practically ill conceived, as it was established without taking into account the actual capability of the labourers.

Of all the four estate allotments, only the Permatang and Rubana labour gardens exhibited remarkable socioeconomic progress. Evidences suggest a transformation of the Tamil settlers into becoming small-scale vendors. The reason is that these allotments were established on a stable economic foundation based on vegetable/food crop gardening and animal rearing. These activities not only provided them sufficient food for consumption but also enabled the sale of vegetable crops, milk supply and meat. Food crops were mainly used for own consumption and only sold when there was a surplus. Livestock such as pigs, cows, goats and cattle were considered valuable economic investments. Their rearing was a productive activity in the 1930s. Livestock farming, particularly, was a rewarding economic enterprise jointly undertaken by the labourers and their family members. Both elderly labourers and the younger ones contributed to the progress of the allotments on the Permatang and Rubana estates. Additionally, the history of the successful garden allotments discussed in this article suggests that sympathetic guidance and encouragement of the estate management was highly required. ${ }^{128}$ More importantly is the observation that the successful progress of labour allotments depended on three interrelated aspects, namely sizeable allotment units, consumable and profitable agricultural produce and livestock farming. The deficiency of any one aspect would ultimately lead to the collapse of the economic foundation of the gardens, consequently affecting the livelihood of the labourers.

\section{Note}

* Mrs. Thivya Ranie Perumal (thiryar@siswa.um.edu.my) holds a Bachelor's Degree in History (majored in Malaysian History and minored in Indian Studies) and is currently pursuing Masters in Malaysian History in History Department, Faculty of Arts and Social Sciences, University of Malaya (UM).

** Associate Prof. Dr. Sivachandralingam Sundara Raja (siva@um.edu.my) is an Associate Professor in History Department, Faculty of Arts \& Social Sciences, University of Malaya (UM).

\footnotetext{
${ }^{1}$ Among the well-known research works pertaining to rubber from the corpus of Malaysian economic history
} are P.T. Bauer, "Some Aspects of the Malayan Rubber Slump 1929-1933”, Economica, Vol. 11, No. 44, 1944, 
pp. 190-198; Richard T. Stillson, "The Financing of Malayan Rubber, 1905-1923", The Economic History Review, Vol. 24, No. 1, 1971, pp. 589-598; J.H. Drabble, "Investment in the Rubber Industry in Malaya C. 1900-1922", Journal of Southeast Asian Studies, Vol. 3, No. 2., 1972, pp. 247-261; J.H. Drabble, "The Plantation Rubber Industry in Malaya up to 1922", Journal of the Malaysian Branch of the Royal Asiatic Society, Vol. 40, No. 1, 1967, pp. 52-77 and; Liew Kain Khiun, "Planters, Estate Health \& Malaria in British Malaya (1900-1940), Journal of the Malaysian Branch of the Royal Asiatic Society, Vol. 83, No. 1, 2010, pp. 91-115. On the other hand, important works on the history of tin development in the Malay states include Arthur W. King, "Changes in the Tin Miing Industry of Malaya", Geography, Vol. 25, No. 3, 1940, pp. 130-134; Wong Lin Ken, The Malayan Tin Industry to 1914, Tucson: University of Arizona Press, 1964; Yip Yat Hoong, The Development of the Tin Mining Industry of Malaya, Kuala Lumpur: University of Malaya Press, 1969; Hideo Yamada, "The Origins of British Colonialization of Malaya with Special Reference to its Tin", The Developing Economics, Vol. 9, Issue 3, 1971, pp. 225-245 and ; Jean-Francois Hennart, "Internationalization in Practice: Early Foreign Direct Investment in Malaysian Tin Mining Industries", Journal of International Business Studies, Vol. 17, No. 2, 1986, pp. 131-143.

${ }^{2}$ For relevant examples, see J.H. Drabble, "Some Thoughts on the Economic Development of Malaya under British Administration", Journal of Southeast Asian Studies, Vol. 5, No. 2, 1974, pp. 199-208 and P.J. Drake, "The Economic Development of British Malaya to 1914: An Essay in Historiography with Some Questions for Historians", Journal of Southeast Asian Studies, Vol. 10, No. 2, 1979, pp. 262-290.

${ }^{3}$ The history of the socioeconomic gap between the least privileged immigrant and native peasant classes and the rich industrial capitalists can be studied from the following works: Ozay Mehmet, "Colonialism, Dualistic Growth and the Distribution of Economic Benefits in Malaysia", Southest Asian Journal of Social Science, Vol. 5, No. 1/2, 1977, pp. 1-21; Paul H. Kratoska, "Rice Cultivation and the Ethnic Division of Labor in British Malaya", Comparative Studies in Society and History, Vol. 24, No. 2, 1982, pp. 280-314 and; Sivachandralingam Sundara Raja and Shivalinggam Raymond, "The Lost Race in British Malaya: Revisiting the Problems of South Indian Labourers", Diaspora Studies, Vol. 11, Issue 2, 2018, pp. 115-134.

${ }^{4}$ Lim Teck Ghee, Peasants and their Agricultural Economy in Colonial Malaya, 1874-1941, Kuala Lumpur: Oxford University Press, 1977, pp. 27-67.

${ }^{5}$ W.I. Ladejinsky, “Agricultural Policies of British Malaya”, Foreign Agriculture: A Review of Foreign Farm Policy, Production and Trade, Vol. 5, 1941, pp. 159-161.

${ }^{66}$ Paul H. Kratoska, "The Peripatetic Peasant and Land Tenure in British Malaya”, Journal of Southeast Asian Studies, Vol. 16, No. 1, 1985, pp. 16-45.

${ }^{7}$ Emily Sadka, The Protected Malay States, 1874-1895, Kuala Lumpur: University of Malaya Press, 1968, pp. 324-327.

${ }^{8}$ Parameswari Krishnan and J. Hinduja Jayer Raman, "Kehidupan Buruh India Ladang di Tanah Melayu”, SEJARAH: Journal of the Department of History, Vol. 28, No. 2, 2019, pp. 55-74.

${ }^{9}$ Khoo Kay Kim, "The Great Depression: The Malaysian Context", in Khoo Kay Kim, ed., The History of South-east, South \& East Asia. Essays \& Documents, Kuala Lumpur: Oxford University Press, 1977, pp. 83-85.

${ }^{10}$ J. Norman Parmer, Colonial Labor Policy and Administration: A History of Labor in the Rubber Plantation Industry in Malaya, 1910-1941, New York: J.J. Augustin Inc., 1960, pp. 144-122.

11 The implementation of the Labour Code from 1912 enforced estate owners to provide housing facilities, which were often in the form of lines for their labourers.In the initial stages following immigration, the labourers were grouped into a form of housing barrack known as lines, where they were stationed for estate works. See K.S. Sandhu, Indians in Malaya: Some Aspects of their Immigration and Settlement (1786-1957), Cambridge: Cambridge University Press, 1969, pp. 218-235 and Amarjit Kaur, "Indian Labour, Labour Standards, and Workers' Health in Burma and Malaya, 1900-1940", Modern Asian Studies, Vol. 40, No. 2, 2006, pp. 425-475.

12 W.S. Cookson, "Food Production on Estates", The Agricultural Bulletin of the Federated Malay States, Vol. 7, 1919, p. 151. On the history of the Dindings district, see Nurulisa Sarah Mohammad Azmil, "Sejarah Daerah Dinding Perak, 1874-1935" (History of the Dinding District of Perak, 1874-1935), M.A. Dissertation, Department of History, Faculty of Arts and Social Sciences, University of Malaya, 2016.

${ }^{13}$ Khoo Kay Kim, "Tanjong, Hilir Perak, Larut and Kinta: The Penang-Perak Nexus in History", in Neil Khor, Khoo Salma Nasution, Loh Wei Leng and Yeoh Seng Guan, eds., Penang and its Region: The Story of Asian Entrepôt, Singapore: NUS Press, 2009, p. 63. See also Nurlisa Sarah Mohammad Azmi, "Peranan British dalam Pembangunan Ekonomi dan Sosial di Jajahan Dinding, 1874-1942", SEJARAH: Journal of the Department of History, Vol. 28, No. 2, 2019, pp. 1-20.

${ }^{14}$ For the history of unemployment and food shortage in the Chinese community of British Malaya during the First World War, see Laurence K. L. Siaw, Chinese Society in Rural Malaysia: A Local History of the Chinese in Titi, Jelebu, Kuala Lumpur: Oxford University Press, 1983, p. 38 and Hin Fui Lim and Tian Yong Fong, The 
New Villages in Malaysia: The Journey Ahead, Kuala Lumpur: Institute of Strategic Analysis \& Policy Research, 2005, p. 25.

${ }^{15}$ On the food shortage crisis from the beginning of the First World War until the outbreak of the Second World War in Malaya, see Lim Teck Ghee, Peasants and their Agricultural Economy.

${ }^{16}$ Cookson, "Food Production on Estates", p. 151.

${ }^{17}$ Ibid.

${ }^{18}$ Ibid.

${ }^{19}$ Ibid., p. 152.

${ }^{20}$ Ibid., pp. 151-153.

21 See Lenore Manderson, Sickness and the State: Health and Illness in Colonial Malaya, 1870-1940, Cambridge: Cambridge University Press, 1996, pp. 94-95.

${ }^{22}$ R.D. Hill, Agriculture in the Malaysian Region, Singapore: NUS Press, 2013, p. 111.

${ }^{23}$ Cookson, "Food Production on Estates", p. 152.

${ }^{24}$ John H. Drabble, Malayan Rubber: The Interwar Years, London: Macmillan Academic and Professional Lts., 1991, p. 18.

${ }^{25}$ Paul H. Kratoska, "Imperial Unity Versus Local Autonomy: British Malaya and the Depression of the 1930s", in Peter Boomgaard and Ian Brown, eds., Weathering the Storm: The Economies of Southeast Asia in the 1930s Depression, Singapore: Institute of Southeast Asian Studies, 2000, p. 285.

${ }^{26}$ United Sua Betong was incorporated on 15 July 1909 by acquisition of three estates in Negeri Sembilan - Sua Betong, Sengkang and Pasir Panjang. The first chairman of the company was Sir William Hood Treacher while K.C.M.G. Guthrie \& Co. Ltd. were the agents and secretaries respectively. The signatory for the Company was John George Hay. Sua Betong Estate commenced tapping in 1911. See C. Northcote Parkinson, The Guthrie Flagship: United Sua Betong, Kuala Lumpur: Malaysian Branch of the Royal Asiatic Society, 1996, p. 126.

${ }^{27}$ Parkinson, The Guthrie Flagship, p. 93.

28 “The Worst Depression Malaya Has Ever Known”, Sunday Tribune, 26 November 1933, p. 14.

${ }^{29}$ Ibid.

30 "Depressed Classes", The Singapore Free Press and Mercantile Advertiser, 12 May 1936, p. 6. Ganapathy was previously a kangany attached to the Company. He entered into service with Sua Betong Estate in 1909 and was usually known as Ganapathy Kangani. See Parkinson, The Guthrie Flagship, p. 138.

31 "Settlement of Indians on the Land", Annual Labour Report 1936, p. 39. See also Khoo Kay Kim, "The Great Depression: The Malaysian Context", pp. 83-85.

32 "Settlement of Indians on the Land", Annual Labour Report 1935, p. 37.

${ }^{33}$ Ibid., p. 36.

34 "Settlement of Indians on the Land", Annual Labour Report 1936, p. 39.

35 "Settlement of Indians on the Land", Annual Labour Report 1937, p. 44.

36 "Indian Settlements in Malaya", The Straits Times, 25 March 1937, p. 5.

37 "Indian Agricultural Settlements", The Straits Times, 20 November 1936, p. 18.

${ }^{38}$ Parkinson, The Guthrie Flagship, p. 94.

${ }^{39}$ Annual Labour Report 1937, p. 45.

${ }^{40}$ Ibid.

${ }^{41}$ In 1937, keen elderly retirees of a Seremban Estate also took up garden cultivation. According to the Labour Department, an elderly former labourer in the estate even claimed that he could have made more than the average \$4-\$5 profit for selling agricultural items by cultivating gardens abandoned by other labourers (Annual Labour Report 1937, p. 47). This particular individual was apparently undertaking cultivation as his full-time occupation.

42 "The Settlement of Tamil Labourers on the Land", The Malayan Agricultural Journal, Vol. 26, No. 11, 1938, p. 455 .

43 John Noel Milsum and Donald Honey Grist, Vegetable Gardening in Malaya, Kuala Lumpur: Straits Settlement Department of Agriculture, 1941, p.141.

${ }^{44}$ Sandhu, Indians in Malaya, pp. 266-267.

45 "The Settlement of Tamil Labourers on the Land", p. 455.

${ }^{46}$ Ibid., pp. 454-455.

47 "Settlement of Indians on the Land", Annual Labour Report 1938, p. 53.

48 Ibid.

${ }^{49}$ Annual Labour Report 1937, p. 45.

50 "Settlement of Indians on the Land", Annual Labour Report 1938, p. 53. Vegetable gardening was also conducted on the Ladang Geddes Estate, owned by the Dunlop Rubber Company. It was conducted on a large scale by allocating lands to the Chinese who were considered more well-adept at gardening than the south Indians (David Sunderland, British Economic Development in South East Asia, 1880-1939 (Volume 3), London: 
Routledge, 2017). The Chinese labourers successfully developed estate gardening while the Tamil labourers shared the benefits. The latter were also exposed to the method of cultivation performed by the Chinese to work their own gardens. It has been stated that the Tamil Village" on the estate was a "paradise". See Shakila Yacob, The United States and the Malaysian Economy, London: Routledge, 2008, p. 109.

51 "Rotation of Crops is of Major Importance", The Straits Times, 13 February 1941, p. 8.

${ }^{52}$ See Ooi Jin Bee, "Some Aspects of Peasant Farming in Malaya", Tijdschrift voor Economische en Sociale Geographie, Vol. 56, 1965, pp. 170-185.

53 "The Settlement of Tamil Labourers on the Land", p. 455.

${ }^{54}$ Ibid.

${ }^{55}$ Annual Labour Report 1938, p. 52.

${ }^{56}$ Ibid., pp. 48-54.

${ }^{57}$ Annual Labour Report 1937, p. 46.

${ }^{58}$ Ibid.

${ }^{59}$ Milsum and Grist, Vegetable Gardening in Malaya, p. 141.

${ }^{60}$ Annual Labour Report 1937, p. 46.

${ }^{61}$ W.N.C. Belgrave, "The Cultivation of Food Crops on Estate", The Malayan Agricultural Journal, Vol. 27, 1939, p. 213.

${ }^{62}$ Ibid.

63 Annual Labour Report 1937, p. 46.

${ }^{64}$ Milsum and Grist, Vegetable Gardening in Malaya, p. 141.

${ }^{65}$ Annual Labour Report 1937, p. 47.

${ }^{66}$ A.W. King, "Plantation and Agriculture in Malaya, with Notes on the Trade of Singapore", The Geographical Journal, Vol. 93, No. 2, 1939, p. 138.

${ }^{67}$ Annual Labour Report 1937, p. 47.

${ }^{68}$ Ibid.

${ }^{69}$ Ibid., p. 45

${ }^{70}$ Milsum and Grist, Vegetable Gardening in Malaya, p. 141.

71 Annual Labour Report 1938, p. 53.

72 Ibid.

73 Annual Labour Report 1937, p. 46.

${ }^{74}$ Ibid.

75 The Telok Gong Estate, Banting, also promoted pig rearing among the labourers by allocating 6 acres of land plots for them to grow food to feed the pigs (Annual Labour Report 1938, p. 52).

76 Albert Howard, The Soil and Health: A Study of Organic Agriculture, Kentucky: University Press of Kentucky, 2011, p. 235.

77 The figures for the year 1938 cover only 28 holdings, as plot owners did not seem to have erected any more houses and only moved to their lands during the production stage (Annual Labour Report 1938, p. 53).

${ }^{78}$ Cattle dung was considered 10-12 times better than the ordinary manure for vegetable gardening. See General Report on the Health of the Estates of the District of Perak for 1939, Content: Nutrients, p. 31, CO 438/5.

79 The Bukit Kledek Estate in Negeri Sembilan promoted cattle rearing among the labourers by providing Frisian bulls (Annual Labour Report 1937, p. 47). In 1938, the labourers built their own cattle sheds with concrete floors with the permission and abiding by the requirements from the Health Department for the supply and sale of milk to an estate in Perak.

${ }^{80}$ Annual Labour Report 1938, p. 52.

${ }^{81}$ Ibid., p. 53.

${ }^{82}$ According to L.A. Vincent, in his Fourteen Miles to Berjuntai (Petaling Jaya: Gerakbudaya Enterprise, 2016), vegetable gardening and animal-keeping were the main economic activities of Tamil labourers and their dependents of the Bristol Estate in Batang Berjuntai, Selangor, towards the end of 1920s and during the Great Depression in the 1930s. Although filled with fictionalized recounts, the memoir does point to the agricultural activities that the labourers undertook. In an instance, it has been mentioned the labourers opened up plots on which they grew kidney beans (avarakai), brinjals, ladies fingers, long beans and green chillies. Betel leaf was one of the important plants cultivated. There were also banana trees. As they kept cows, there was apparently no problem in acquiring manure and dung for fertilizer. Fresh cow milk were bottled for sale. Surplus vegetables were sold to the estate's toddy shop. In the 1930s, at the onset of the Great Depression, those who chose to remain in Malaya survived by consuming homegrown vegetables. In 1936, some former labourers returned and continued working on the plantation while cultivating and rearing cows in their spare time. The author mentions that in the 1940s, when the Japanese occupied Malaya, tappers made ends meet by cultivating their vegetable plots.

${ }^{83}$ Annual Labour Report 1938, p. 53. 
${ }^{84}$ Annual Labour Report 1937, p. 47.

${ }^{85}$ Ibid.

${ }^{86}$ Sandhu, Indians in Malaya, p. 266. Sandhu further mentions that the allotment might have been reinvigorated during the post-war years but would have quickly degenerated in post-independent Malaya with the implementation of the Emergency Regulation. The settlers were then forced to abandon their plots and revert to their labour lines due to the querrilla campaign and the intensification of anti-insurgency measures by the British (p. 266). Additionally, substantial insights into the economic policy of the Japanese administration in occupied Malaya, particularly as regards the rubber industry, are provided in Yoshumura Mako, "Japanese Occupation and Economic Policy in Malaya”, SEJARAH: Journal of the Department of History, Vol. 10, No. 2, 2002, pp. 21-51.

${ }^{87}$ R.G. Watson, "The Land Laws and Land Administration of the Federated Malay States", Agricultural Bulletin of the Straits and Federated Malay States, Vol. VIII, No. 5, May 1909, p. 218. The Rubana Estate is particularly noted to be among the first to demonstrate sustained sugar planting in the FMS from 1899. It shifted to rubber cultivation partly because it was unable to prevent rodent-borne contagious disease, responsible for destroying most of the cane crops. See Lynn Hollen Lees, Planting Empire, Cultivating Subjects: British Malaya, 17861941, Cambridge: Cambridge University Press, 2017, p. 177 and I. Wray, "Notes on the Sugar Cane Rat, Mus Jalorensis”, Journal of the Federated Malay States Museums, Vol. 1, Issue 2, 1905, p. 40.

${ }^{88}$ Annual Labour Report 1938, p.53.

${ }^{89}$ Ibid., p. 51.

90 “The Settlement of Tamil Labourers on the Land", The Malayan Agricultural Journal, Vol. 26, No. 11, 1938, p. 455.

91 Ibid.

92 There were also labour cottages each with gardening plots for the labourers of the Temiang Estate of Negeri Sembilan in the Sungei Kaya Division (Annual Labour Report 1937, p. 47). On the Ulu Bernam Estate, there were semi-detached houses with experimental gardens, said to be as successful as those on Rubana (Annual Labour Report 1938, p. 50).

93 Annual Labour Report 1937, p. 43.

94 "The Settlement of Tamil Labourers on the Land", p. 455.

95 Annual Labour Report 1937, p. 43.

${ }^{96}$ Ibid.

97 “The Settlement of Tamil Labourers on the Land", p. 455.

${ }^{98}$ Ibid.

${ }^{99}$ Ibid.

${ }^{100}$ Crop rotation played an important role in maintaining the fertility of arable land. Legumes such as cow pea, kidney bean, four-angled bean, and ground nut were recommended to be planted firstly on the land, followed by cereal such as millet and maize, then root vegetables such as sweet potato, yam and Jerusalem artichoke. For the second time, the legumes were to be planted again. In the fifth rotation, brinjal and chilli were to be selected. Following that, it was suggested that any other vegetable could be planted on the land. Leafy vegetables such as bayam, asin-asin of Chinese white greens, and ladies fingers were planted as the last crops. See, General Report on the Health of the Estates of the District of Perak for 1939, Content: Nutrients, p. 32, CO: 438/5.

101 Ibid., p. 457.

102 Ibid. See also "Foodstuff Cultivation: Good Progress Noticeable on Some Estates", The Straits Times, 21 August 1918, p. 10.

103 "The Settlement of Tamil Labourers on the Land", p. 455. It is estimated some 200 Tamil families in Perak, especially in Sitiawan, started rearing pigs as a means of augmenting their income (Proceedings of the Federal Council of the Federated Malay States for the year 1938, Kuala Lumpur: Federated Malay States Government Press, 1939, p. C309).

${ }^{104}$ Ibid., p. 457. The Gedong Estate management of Bagan Serai, Perak, undertook a similar initiative. A truck farm, established in 1937-1938, was maintained and managed by a skilled farmer who demonstrated proper methods of cultivation to the laboureres and to their school-going children (Annual Labour Report 1938, p. 51). 105 Ibid. On some estates, grazing areas were fenced and planted with guinea grass.

106 "The Settlement of Tamil Labourers on the Land", p. 457.

${ }^{107}$ Milsum and Grist, Vegetable Gardening in Malaya, p. 142.

108 Annual Labour Report 1938, p. 50.

${ }^{109}$ S. Nanjundan, Indians in Malayan Economy, New Delhi: Manager of Publications, 1950, p. 34.

${ }^{110}$ Sandhu, Indians in Malaya, p. 265 and "The Settlement of Tamil Labourers on the Land", pp. 445-457.

${ }^{111}$ On some estates in Selangor, for example, spaces for recreation, goat grazing and gardens were allocated for all labour lines. See, Annual Report of the Social and Economic Progress of the People of Selangor for the year 1937, p. 30, CO 439/4. 
${ }^{112}$ In 1915, the Petaling Estate or Petaling Village in Kuala Lumpur set aside a list of provision items to be sold. The following are some of the items and their regulated price rate per kati: vegetables per kati (0.03-0.30 cents); dhalls per kati (0.10-0.14 cents); tamarind per kati (0.08 cents); onions per kati (0.08-0.18 cents); coconut oil (0.22-0.24 cents); gingirly oil (0.28 cents); coconut (0.05-0.07 cents); salt per chipal (0.04 cents); sugar per kati ( 0.12 cents); sojee per kati (0.14-0.16 cents); salted fish per kati (0.10-0.40) cents; eggs per dozen (0.36-0.43 cents); turmeric in small quantities; fresh fish per kati; coriander seeds per chipal (0.10-0.12 cents); pepper per kati $(0.25$ cents); chillies per kati (0.16 cents); cumin seeds per kati ( 0.48 cents); mustard per kati ( 0.18 cents); and condensed milk per tin (0.24 cents). See, "Prices of foodstuffs at Petaling Village", from F.G. Harvey, Petaling Estate Kuala Lumpur, 21 July 1915, SEL: SEC: 3743/1915. A labourer might have been able to save up to approximately $\$ 1.26$ if food crops such as onions, vegetables, turmeric, chillies were cultivated and milk and eggs obtained from livestock. On most estates, rice was usually supplied by the management. Provision shops were generally placed under the supervision of estate managements. In a few places, there were shops run by labourers themselves on a co-operative basis (Annual Report of the Agent of the Government of India in British Malaya 1936, Delhi: Government of India Press, 1937, p. 11).

${ }^{113}$ See Paul H. Kratoska, "Rice Cultivation and the Ethnic Division of Labour in British Malaya", Comparative Studies in Society and History, Vol. 24, No. 2, 1982, pp. 280-314.

114 "Vegetable Gardening in Malaya IV: Rotation of Crops is of Major Importance", The Straits Times, 13 February 1941.

115 Ibid., pp. 143-144.

116 V.S. Sastri, Reprint of Report on the Conditions of Indian Labour in Malaya, Kuala Lumpur: Federated Malay States Government Press, 1937, p. 89. Labourers of the Hollyrood Estate, Perak, for example, cultivated betel leaves mainly for sale and vegetables for consumption (Annual Labour Report 1938, p. 51).

117 "Vegetable Gardening in Malaya IV: Rotation of Crops is of Major Importance", The Straits Times, 13 February 1941, p. 36 and Milsum and Grist, Vegetable Gardening in Malaya, p. 148.

118 School Gardens were originally established in Perak to encourage the Malays to show more involvement in agricultural activities: offering advice on matters relating to agriculture, procuring suitable seeds, teaching the younger ones the proper use of tools and effective cultivation methods. The initiative was extended to the Tamil labouring community, as indicated when a pamphlet, prepared by an Agricultural Office of Selangor, was translated into the Tamil language and published in the Tamil Agricultural Journal (Ezwan Arman, Mohd Zufri Mamat and Maisarah Hasbullah, "Agricultural Education as a Medium for the Trasmission of Western Science during British Rule in Malaya, 1905-1957”, History of Education: Journal of History and Education Society, Vol. 45, Issue 5, 2016, p. 5). From 1937 onwards, a number of estate school managements exposed to the children of labourers the art of gardening and matters pertaining to proper cultivation ("Settlement of Indians on the Land", Annual Labour Report, 1937, p. 47). The Assistant Controller of Labour reported in 1938 that the estate gardens in Negeri Sembilan, for example, were located near estate schools where the children were taught to grow vegetables and flowers.

119 "Foodstuff Cultivation: Good Progress Noticeable on Some Estates", The Straits Times, 21 August 1918, p. 10 .

${ }^{120}$ Annual Report of the Social and Economic Progress of the People of Selangor for the year 1937, p. 30. The Veterinary Department provided advice in all matters relating to livestock and the genetical aspects of animal breeding. For an example, in Negeri Sembilan, the Veterinary Department undertook the inspection and licensing of cattle sheds and dairies outside the Sanitary Boards areas. The Health Department also regulated the supply and sale of milk by the labourers. In Selangor, dairy supervision in the Kuala Lumpur area was carried out with the help of officers from the health department (Annual Labour Report 1938).

${ }^{121}$ Annual Report of the Social and Economic Progress of the People of Perak for the year 1938, p. 47, CO 438/5.

122 Editorial Note on "Tamil Land Settlements", The Malayan Agricultural Journal, Vol. 26, No. 11, 1938, p. 449.

${ }^{123}$ Editorial Note on "Tamil Land Settlement", p. 449.

124 In Selangor, North Indians also undertook milk trade. See Annual Report of the Social and Economic Progress of the People of Selangor for the year 1937, p. 30.

${ }^{125}$ H. Walker, "Livestock on Estates", The Malayan Agricultural Journal, Vol. 28, 1940, p. 71.

${ }^{126}$ Ibid., p. 70.

${ }^{127}$ A manager of an estate reported that his labourers considered the breeding of their 45 cows and calves and 60 goats a better form of investments than saving money in deposit accounts. A calf, costing $\$ 10-\$ 15$, was worth up to $\$ 50$ in $21 / 2$ years and $\$ 60-\$ 70$ in $31 / 2$ years (Annual Labour Report 1938, p. 51).

${ }^{128}$ Milsum and Grist, Vegetable Gardening in Malaya, p. 141. 


\section{REFERENCE}

\section{UNPUBLISHED PRIMARY SOURCES}

\section{Annual/Department Report}

Acting Controller of Labour Inspection Report

Annual Report of the Agent of the Government of India in British Malaya, 1923-1924

Controller Labour Report

Labour Office Port Dickson Files (LOPD)

\section{Colonial Office File}

CO 435/3-4, 1906-1929 (Negeri Sembilan Sessional Papers)

CO 439/4, 1925-1939 (Selangor Sessional Papers)

\section{District Office File}

District Office, Port Dickson: Chuah Indian Settlement File

\section{Proceeding of the FMS Federal Council}

Malay States Federated: Federal Council Proceedings, 1909-1921

\section{Secretariat File}

Negeri Sembilan Government Files

Selangor Secretariat Files, 1900-1941

\section{Miscellaneous}

Indian Cooperative Office Negeri Sembilan Files (ICONS)

\section{PUBLISHED PRIMARY SOURCES}

\section{Book}

Hands, J., The History of the Malay Agricultural Settlement in Kuala Lumpur: Compilation of Minute Books from January 1899 to October 1941, Kuala Lumpur: Malaysia Agricultural Settlement Office, 1941.

Milsum, J.N., and Grist, D.H., Vegetable Gardening in Malaya, Kuala Lumpur: Straits Settlement Department of Agriculture, 1941. 


\section{Bulletin}

Bulletin of the Department of Agriculture Straits Settlements and the Federated Malay States, 1902-1912, Singapore: Government Printing Office.

The Agricultural Bulletin of the Federated Malay States, 1912-1921, Kuala Lumpur: Federated Malay States.

\section{Journal}

Journal of the Federated Malay States Museums, 1905-1941, Kuala Lumpur: The Museums.

Malayan Agricultural Journal, 1912-1941, Kuala Lumpur: Department of Agriculture.

\section{Official Proceeding}

Proceedings of the Federal Council of the FMS, 1909-1941, Kuala Lumpur: Government Press.

Proceedings of the First Agricultural Conference, Malaya, held at the Chamber of Commerce, Kuala Lumpur, April $25^{\text {th }}$ to $28^{\text {th }}, 1917$.

\section{Official Report}

Annual Report of the Agent of the Government of India to Malaya, 1925-1940, Delhi: Government of India Press.

Annual Report of the Labour Department of the Federation of Malaya, 1912-1940, Kuala Lumpur: Federated Malay States.

Annual Report of the Working of Co-operative Societies in the FMS and SS, 1925-1931.

Sastri, V.S. Srinivasa., Reprint of Report on the Conditions of Indian Labour in Malaya, Kuala Lumpur: Federated Malay States Press, 1937.

\section{SECONDARY SOURCES}

\section{Book}

Ahmad Ibrahim and Sihombing, Judith, The Centenary of the Torrens Systems in Malaysia, Singapore: Malayan Law Journal; St.Paul, Minn: Butterworth Legal Publishers, 1989.

Ahmad Nazri Abdullah, Melayu dan Tanah, Petaling Jaya: Media Intelek Sdn. Bhd., 1985.

Allen, G.C., Donnithorne, A.G., Western Enterprise in Indonesia and Malaya, Oxon: Routledge, 1957. 
Ampalavanar, R., The Indian Minority and Political Change in Malaya (1945-1957), Oxford: Oxford University Press, 1981.

Amrith, S.S., Crossing the Bay of Bengal, Harvard: Harvard University Press, 2013.

Andaya, B.W. and Andaya, L.Y., A History of Malaysia, Hampshire: Palgrave MacMillian, 2001.

Basu, R.S., Nandanar's Children: The Paraiyan'Tryst with Destiny, Tamil Nadu 1850 1956, Los Angeles: SAGE Publications, 2011.

Beteille, A., Caste, Class, and Power: Changing Patterns of Stratification in a Tanjore Village, Los Angeles: University of California Press, 1965.

Carl, V.B., Tragic Orphans: Indians in Malaysia, Singapore: Institute of Southeast Asian Studies, 2015.

Carter, M., Voices from Indenture: Experiences of Indian Migrants in the British Empire, London: Leicester University Press, 1996.

Chai Hon Chan, The Development of British Malaya, 1896-1900, Kuala Lumpur: Oxford University Press, 1967.

Drabble, J.H., An Economic History of Malaysia, c. 1800-1990: The Transition to Modern Economic Growth, London: Palgrave MacMillan, 2000.

Drabble, J.H., Malayan Rubber: The Interwar Years, London: Macmillan Academic and Professional Lts., 1991.

Hill, R.D., Agriculture in the Malaysian Region, Singapore: NUS Press, 2013.

Hill, R.D., Rice in Malaya: A Study in Historical Geography, Singapore: NUS Press, 2012.

Howard, A., The Soil and Health: A Study of Organic Agriculture, Kentucky: University Press of Kentucky, 2011.

Jackson, R.N., Immigrant Labour and the Development of Malaya (1786-1920): A Historical Monograph, Kuala Lumpur: Government of the Federation of Malaya, 1961.

Jain, R.K., South Indians on the Plantation Frontier in Malaya, New York: Yale University Press, 1970.

Judge, Paramjit S., and Bal, Gurpreet, Strategies of Social Change in India, New Delhi: MD Publication Pvt. Ltd., 1996.

Kumar, D., Land and Caste in India: Agricultural Labour in the Madras Presidency during the Nineteenth Century, Cambridge: Cambridge University Press, 1965. 
Ladejinsky, W.I., Agricultural Policies of British Malaya, Washington, D.C: U.S. Dept. of Agriculture, Foreign Agricultural Service, 1941.

Lees, L.H., Planting Empire, Cultivating Subjects: British Malaya, 1786-1941, Cambridge: Cambridge University Press, 2017.

Li Dun Jen, British Malaya: An Economic Analysis, Kuala Lumpur: Nadi Ihsan, 1982.

Lim Teck Ghee, Origins of a Colonial Economy: Land and Agriculture in Perak 18741897, Penang: Universiti Sains Malaysia Press, 1976.

Lim Teck Ghee, Peasants and their Agricultural Economy in Colonial Malaya, 1874-1941, Kuala Lumpur: Oxford University Press, 1977.

Mahajani, U., The Role of Indian Minorities in Burma and Malaya, New York: Institute of Pacific Relations, 1960.

Manderson, L., Sickness and the State, Health and Illness in Colonial Malaya, 1870-1940, Cambridge: Cambridge University Press, 1996.

Manikumar, K.A., A Colonial Economy in the Great Depression, Madras (1929-1937), Hyderabad: Orient Longman, 2003.

Meek, C.K., and Hailey, B.W.M.H., Land Law and Customs in the Colonies, London: Oxford University Press, 1949

Mills, L.A., British Malaya, 1824-1867, Singapore: Malayan Branch of the Royal Asiatic Society, 1961.

Mills, L.A., Malaya: A Political and Economic Appraisal, London: University of Minnesota Press, 1958.

Nair, M.N., Indians in Malaya, Koduvar: Koduvar Press, 1937.

Nanjundan, S., Indians in Malayan Economy, New Delhi: Manager of Publications, 1950.

Neelakandha Aiyer, K.A., Indian Problems in Malaya, Kuala Lumpur: The Indian Office, F.M.S., 1938.

Netto, George, Indians in Malaya: Historical Facts and Figures, Singapore, 1961.

Panchanadikar, K.C., and Panchanadikar, J., Rural Modernization in India: A Study in Developmental Infrastructure, Bombay: Popular Prakashan, 1978.

Parkinson, C.N., The Guthrie Flagship: United Sua Betong, Kuala Lumpur: Malaysian Branch of the Royal Asiatic Society, 1996.

Parmer, J.N., Colonial Labour Policy and Administration: A History of Labour in the Rubber Plantation Industry in Malaya, s. 1910-1941, New York: J.J. Austin, 1960. 
Pillai, S., Colonial Visions, Postcolonial Revisions Images of the Indian Diaspora Malaysia, Cambridge: Cambridge Scholars Publishing, 2007.

Pratap Kumar, P., Indian Diaspora: Socio-cultural and Religious Worlds, Leiden: Koninklijke Brill NV, 2015.

Ramasamy, R., Caste Consciousness among Indian Tamils in Malaysia, Petaling Jaya: Pelanduk Publications, 1984.

Ramaswamy, V., Historical Dictionary of the Tamils, Lanham: Rowman \& Littlfield, 2017.

Sadka, Emily, The Protected Malay States, 1874-1895, Kuala Lumpur: University of Malaya Press, 1968.

Salleh Haji Buang, Malaysian Torrens System, Kuala Lumpur: Dewan Bahasa dan Pustaka, 1995.

Sandhu, K.S., Indians in Malaya: Some Aspects of their Immigration and Settlement (1788 1957), London: Cambridge University Press, 1969.

Shakila Yacob, The United States and the Malaysian Economy, London: Routledge, 2008.

Sidhu, J.S., Administration in the Federated Malay States 1896-1920, Kuala Lumpur: Oxford University Press, 1980.

Sikri, Veena, India and Malaysia: Intertwined Strands, Singapore: ISEAS Publishing, 2013.

Sinnappah, A., Indians in Malaysia and Singapore, Kuala Lumpur: Oxford University Press, 1970.

Stenson, M., Class, Race and Colonialism in West Malaysia: The Indian Case, Queensland: University of Queensland Press, 1980.

Sunderland, D., British Economic Development in South East Asia, 1880-1939 (Volume 1), London: Routledge, 2015.

Thompson, V., and Adloff, R., Minority Problems in Southeast Asia, Stanford: Stanford University Press, 1955.

Thompson, V., Labor Problem in Southeast Asia, New Haven: Yale University Press, 1947.

Vincent, L.A., Fourteen Miles to Berjuntai, Petaling Jaya: Gerakbudaya Enterprise, 2016.

Voules, A.B., The Laws of the Federated Malay States, 1877-1920, (Vol. II), London: Hazell, Watson \& Viney, Ld., 1921. 
Wiebe, P.D., and Mariappen, S., Indian Malaysians: The View from the Plantation, New Delhi: Manohar Publications, 1978.

Wilson, H.E., The Klang Strikes of 1941: Labour and Capital in Colonial Malaya, Singapore: Institute of Southeast Asian Studies (ISEAS), 1981.

Wong, D.S.Y., Tenure and Land Dealings in the Malay States, Singapore: Singapore University Press, 1975, p. 65.

\section{Chapter in Book}

Amrith, S.S., "Connecting Diaspora Histories: Indians and Chinese in Colonial Malaya", in Jayati Bhattacharya, Coonoor Kripalani, eds., Indian and Chinese Immigrant Communities Comparative Perspectives, London: Anthem Press, 2015, pp.13-23.

Jain, R.K., "South Indian Labour in Malaya, 1840-1920: Asylum Stability and Involution", in Kay Saunders, eds., Indentured Labour in the British Empire 1840-1920, London: Routledge, 2018, pp. 158-182.

Kaur, Amarjit, "Indians in South-East Asia: Migrant Labour, Knowledge Workers and New India", in Rai and Peter Reeves, eds., The South Indian Diaspora: Transnational Networks and Changing Identities, New York: Routledge, 2008, pp. 71-88.

Kaur, A., "Sojourners and Settlers: South Indians and Communal Identity in Malaysia",in Crispin Bates, ed., Community, Empire and Migration: South Asians in Diaspora, New Delhi: Palgrave MacMillan, 2001, pp. 185-205.

Khoo Kay Kim, "Tanjong, Hilir Perak, Larut and Kinta: The Penang-Perak Nexus in History", in Neil Khor, Khoo Salma Nasution, Loh Wei Leng and Yeoh Seng Guan, eds., Penang and its Region: The Story of Asian Entrepôt, Singapore: NUS Press, 2009, pp. 54-82.

Khoo Kay Kim, "The Great Depression: The Malaysian Context”, in Khoo Kay Kim, ed., The History of South-east, South \& East Asia: Essays \& Documents, Kuala Lumpur: Oxford University Press, 1977, pp. 78-94.

Kratoska, P.H., "Imperial Unity Versus Local Autonomy: British Malaya and the Depression of the 1930s", in Peter Boomgaard and Ian Brown, eds., Weathering the Storm: The Economies of Southeast Asia in the 1930s Depression, Singapore: Institute of Southeast Asian Studies, 2000, pp. 271-294.

Lal, Brij. V., "Indian Indenture: Experiment and Experience", in Jaya Chatterji and David Washbrook, eds., Routledge Handbook of the South Asian Diaspora, London: Routledge, 2013, pp. 79-95.

Mako Yoshimura, “Japan's Economic Policy for Occupied Malaya”, in Yōji Akashi and Mako Yoshimura, eds., New Perspectives on the Japanese Occupation in Malaya and Singapore, 1941-1945, Singapore: NUS Press, 2008, pp. 113-138. 
Mari Fujita, "Global Architecture and Ethnic Enclaves: Reading Kuala Lumpur's City Centre", in Vinayak Bharne, ed., The Emerging Asian City: Concomitant Urbanities and Urbanisms, New York: Routledge, 2013, pp. 183-192.

Ramasamy, P., "Labour Control and Labour Resistance in the Plantations of Colonial Malaya", in E. Valentine Daniel, Henry Bernstern, and Tom Brass, eds., Plantation, Proletarians, and Peasants in Colonial Asia, London: Frank Cass \& Co. Ltd, 1992, pp. 87-105.

Sahoo, A.K., "Studying Diaspora Online: Migration, Community Formation and Transnational Networks", in Ajaya Kumar Sahoo, ed., Sociological Perspectives on Globalisation, Delhi: Kalpaz Publications, 2006, pp. 286-308.

Sandhu, K.S., "The Coming of the Indians to Malaysia", in Sandhu and A. Mani, eds., Indian communities in Southeast Asia, Singapore: Institute of Southeast Asian Studies, 2006, pp. 151-189.

Selvaratnam, T., "Indian Plantation Workers in West Malaysia", in Aniruth Gupta, ed., Indians Abroad: Asia and Africa, Report of an International Seminar, New Delhi: Orient Longman, 1971, pp. 141-142.

Smith, T.E., "Immigration and Permanent Settlement of Chinese and Indians in Malaya: And The Future Growth of the Malay and Chinese Communities", in C.D. Cowan, ed., The Economic Development of South-East Asia, Oxon: Routledge Revivals, 1964, pp. 174-185.

Walinsky, L.J., "Agricultural Policies of British Malaya", in Louis J. Walinsky, ed., Agrarian Reform as Unfinished Business: The Selected Papers of Wolf Ladejinsky, New York: Oxford University Press, 1977.

\section{Journal Article}

Arasaratnam, S., "Indian Society of Malaysia and Its Leaders: Trends in Leadership and Ideology among Malaysian Indians, 1945-1960", Journal of Southeast Asian Studies, Vol. 13, No. 2, 1962, pp. 236-251.

Adapa, S., "Globalization and the Telugu (South India) Diaspora in SoutheastAsia, 1871-1964", Proceedings of the Indian History Congress, Vol. 6, 2006/2007, pp. 845-858.

Buss-Tjen, P.P., "Malay Law", The American Journal of Comparative Law, Vol. 7, No. 2, 1958, pp. 254-257.

Datta, A., "Tracing the Roots of Marginalization in Malaysia" Alienation of "Bhumiputras" during the Colonial Period", Proceedings of the Indian History Congress, Vol. 71, 2010/2011, pp. 900-910.

Drake, P.J., "The Economic Development of British Malaya to 1914: An Essay in Historiography with Some Questions for Historians", Journal of Southeast Asian Studies, Vol. 10, No, 2, 1979, pp. 262-290. 
Ezwan Arman, Mohd Zufri Mamat and Maisarah Hasbullah, "Agricultural Education as a Medium for the Trasmission of Western Science during British Rule in Malaya, 1905 1957”, History of Education: Journal of History and Education Society, Vol. 45, Issue 5, 2016, pp. 1-15.

Fee, Micheal, (Father), "Kampong Padre: A Tamil Settlement near Bagan Serai Perak, Perak, by Father Fee translated by Father Manikam, with an introduction by R.K. Jain", Journal of the Malayan Branch of the Royal Asiatic Society, Vol. 36, Pt. 1, 1963, pp. 153-181.

Hirschman, C., "Demographic Trends in Peninsular Malaya, 1945-75", Population and Development Review, Vol. 6, Issue 1, 1980, pp. 103-125.

Hirschman, C., "The Making of Race in Colonial Malaya: Political Economy and Racial Ideology", Sociological Forum, Vol. 1, No.2, 1986, pp. 330-361.

Huff, W.G., "Entitlements, Destitution, and Emigration in the 1930s Singapore Great Depression", The Economic History Review, Vol. 54, No. 2, 2001, pp. 290-232.

Kaur, A., "Labor Crossings in Southeast Asia: Linking Historical and Contemporary Labor Migration", New Zealand Journal of Asian Studies, Vol. 1, No.1， 2009， pp. 276-303.

Jomo, K.S., "Colonial Land Law, Property Rights and Malay Peasant Inequalities:Ungku Aziz on Land Subdivision and its Consequences", Institutions and Economies, Vol. 7, No. 3, October 2015, pp. 20-38.

Kaur, A., "Indian Labour, Labour Standards, and Workers' Health in Burma and Malaya, 1900-1940", Modern Asian Studies, Vol. 40, No. 2, 2006, pp. 425-475.

Khoo Kay Kim, "The First Indian Member of the Federal Legislative Councils", Malaysia in History, XVI/1, 1973, pp. 3-4.

Khoo Kay Kim, "The Indian Association Movement in Peninsular Malaysia: The Early Years', Journal of the Malaysian Branch of the Royal Asiatic Society (JMBRAS), Vol. 65, No. 2, 1992, pp. 3.24.

King, A.W., "Plantation and Agriculture in Malaya, with Notes on the Trade of Singapore", The Geographical Journal, Vol. 93, No. 2, 1939, pp. 134-148.

Kratoska, P.H., "Ends that We Cannot Foresee: Malay Reservations in British Malaya", Journal of Southeast Asian Studies, Vol. 14, No. 1, 1983, pp. 149-168.

Kratoska, P.H., "Rice Cultivation and the Ethnic Division Labor in British Malaya", Comparative Studies in Society and History, Vol. 24, No. 2, 1982, pp. 280-314.

Kratoska, P.H., "Post-1945 Food Shortage in British Malaya", Journal of Southeast Asian Studies, Vol. 19, No. 1, 1988, pp. 27-47.

Krishnan, P., and J. Raman, H.J., "Kehidupan Buruh India Ladang di Tanah Melayu", SEJARAH: Journal of the Department of History, Vol. 28, No. 2, 2019, pp. 55-74.

Ladejinsky, W.I., “Agricultural Policies of British Malaya”, Foreign Agriculture: A Review of Foreign Farm Policy, Production and Trade, Vol. 5, 1941, pp. 159-164. 
Liew Kai Khiun, "Planters, Estate Health and Malaria in British Malaya (1900-1940)", Journal of the Malaysian Branch of the Royal Asiatic Society (JMBRAS), Vol. 83, No. 1, 2010, pp. 91-115.

Mako, Y., "Japanese Occupation and Economic Policy in Malaya", SEJARAH: Journal of the Department of History, Vol. 10, No. 2, 2002, pp. 21-51.

$\mathrm{Ng}$ Siew Yoong, "The Chinese Protectorate in Singapore 1877-1900", Journal Southeast Asian History, Vol. 2. No.1, Issue: The Chinese in Malaya, 1961, pp. 76-99.

Nor Asiah Mohamad and Bashiiran Begum Mubarak Ali, "The Prospects and Challenges of Malay Reservation Land in the 21st Century", Malaysian Journal of Real Estate, Vol. 4, No.2, 2009, pp. 1-16.

Nurlisa Sarah Mohammad Azmi, "Peranan British dalam Pembangunan Ekonomi dan Sosial di Jajahan Dinding, 1874-1942", SEJARAH: Journal of the Department of History, Vol. 28, No. 2, 2019, pp. 1-20.

Ooi Jin Bee, "Some Aspects of Peasant Farming in Malaya", Tijdschrift voor Economische en Sociale Geographie, Vol. 56, 1965, pp. 170-185.

Ooi Jin Bee, "The Rubber Industry of the Federation of Malaya", Journal of Tropical Geography, Vol. 15, 1961, pp. 46-65.

Ramasamy, R., "The Role of Caste in the Migration of Indian Tamils to Malaysia", Journal of the Malaysian History Society, Vol. 25, 1982, pp. 47-58.

Sandhu, K.S., "Some Preliminary Observation of the Origins and Characteristics of Indian Migration to Malaya 1786-1957”, Intisari, Vol. 3, No. 4, pp. 22-40.

Raja, S.S., and Raymond, S., "The Lost Race in British Malaya: Revisiting the Problems of South Indian Labourers", Diaspora Studies, Vol. 11, No. 2, 2018, pp. 1-20.

Turner, G.E., "A Perak Coffee Planter's Report on The Tamil Labourers in Malaya in 1902”, The Malayan Historical Journal, Vol. 2, No. 1, 1955, pp. 20-28.

Voon Phin-Keong, "Rural Land Ownership and Development in the Malay Reservations of Peninsular Malaysia”, South East Asian Studies, Vol. 14, No. 4, 1977, pp. 496-512.

Wilson, H.E., "The Evolution of Land Administration in the Malay States: A Survey of British-Inspired Changes", Journal of the Malaysian Branch of the Royal Asiatic Society (JMBRAS), Vol. 48, No. 1, 1975, pp. 120-133.

Yutaka Shimomoto, "Agricultural Development Policy in West Malaysia", Jurnal Southeast Asian Studies, Vol. 18, No. 1, 1980, pp. 92-109.

\section{Conference Paper}

Jain, R.K., "Ramanathapuram Experiment: Paradigm of an Estate-Farm-Factory Community in Malaya", Proceedings of the First International Conference Seminar of Tamil Studies, Kuala Lumpur: International Association of Tamil Research, April 1966. 
Oorjitham, K.S. Susan, "The Tamil Working Class in Peninsular Malaysia", International Conference Seminar of Tamil Studies, Kuala Lumpur, 15-19 November 1987.

Satyanarayana, A., "Birds of Passage - Migration of South Indian Labour Communities to South-East Asia, 19-20 ${ }^{\text {th }}$ Centuries, A.D.", IIAS/IISG, CLARA Working Paper, No. 11, Amsterdam: International Institute of Social History, 2001.

Strauch, J., "Settlement and Resettlement: Political and Economic Implications for Chinese Minorities", in Proceedings of the Southeast Asian Tribal Groups and Ethnic Minorities, Cambridge: Department of Anthropology Cultural Survival Inc, Harvard University, 1987.

\section{Thesis/Dissertation/Academic Exercise}

Kaur, A., "North Indians in Malaya: A Study of their Economic, Social and Political Activities with Special Reference to Selangor, 1870s-1940s", M.A. Dissertation, Department of History,University of Malaya, 1973.

Krishnan, P., "Todi dalam kalangan Masyarakat India Ladang di Tanah Melayu, 1900-1957" (Toddy in the Indian Plantation Community in Malaya,1900-1957), Ph.D. Thesis Department of History, University of Malaya, 2014.

Nurulisa Sarah Mohammad Azmil, "Sejarah Daerah Dinding Perak, 1874-1935”, Masters Dissertation, Department of History, University of Malaya, 2016.

Perumal, T.R., "Peranan British dalam Perkembangan Petempatan Pertanian Buruh India Selatan pada Abad ke-20" (British Role in the Development of South Indian Labour Agricultural Settlement in the $20^{\text {th }}$ Century), Academic Exercise (B.A.), Department of History, 2014/2015.

Rengasamey, P.A., "Perkembangan dan Peranan South Indian Labour Fund,1907-1999" (The Development and Roles of the South Indian Labour Fund, 1907-1999), Ph.D. Thesis, Department of History, University of Malaya, 2016.

Subramanian, S., "Penglibatan Central Indian Association of Malaya dalam Isu Buruh India di Tanah Melayu" (The Involvement of the Central Indian Association of Malaya in the Issue of South Indian Labourers in Malaya), M.A. Dissertation, Department of History, 2015.

Sumarni binti Sainawi, "Kemasukan Buruh Cina dan India di Negeri Selangor, 1890-1941" (The Coming of Chinese and Indian Labourers into Selangor, 1890-1941), Academic Exercise (B.A.), Department of History, 2012/2013.

Superno, D.E., "Tamils in Malaysia: Problems in Socioeconomic Development for an Immigrant Minority Group”, Ph.D. Thesis, Rice University, 1983.

Perumal, R., "Keadaan Sosial Buruh India di Tanah Melayu, 1931-1957” (Social Conditions of Indian Labourers in Malaya, 1931-1957), Academic Exercise (B.A.), Department of History, 2003/2004. 


\section{Newspaper}

Sunday Tribune, $(1930$ - 1940)

The Singapore Free Press and Mercantile Advertiser, (1900 - 1941)

The Straits Times, $(1900-1940)$ 